\title{
Production of aminopeptidase by marine heterotrophic nanoflagellates
}

\author{
B. R. Mohapatra ${ }^{1,2, *}$, K. Fukami \\ ${ }^{1}$ Laboratory of Aquatic Environmental Sciences, Faculty of Agriculture, Kochi University, Otsu 200, Monobe, \\ Nankoku, Kochi 783-8502, Japan \\ ${ }^{2}$ Present address: CANMET Materials Technology Laboratory, Natural Resources Canada, 568 Booth Street, Ottawa, \\ Ontario K1A 0G1, Canada
}

\begin{abstract}
In order to examine the hypothesis that the enzyme levels of heterotrophic nanoflagellates (HNF) are influenced by qualitatively different food bacteria, the production of aminopeptidase by an isolated marine HNF Jakoba libera-5(2) fed on natural communities of bacteria and 6 bacterial strains of 5 different taxonomic groups (Aeromonas, Bacillus, Coryneforms, Flavobacterium and Pseudomonas) were compared. The aminopeptidase activity (total and free) and abundance of J. libera-5(2) significantly differed with the types of food bacteria. The total and free aminopeptidase activities and abundance of $J$. libera-5(2) were at a maximum with Pseudomonas spp., followed by Flavobacterium sp. and natural communities of bacteria as prey. The values of total aminopeptidase activity of J. libera-5(2) with Pseudomonas spp., Flavobacterium sp. and natural communities of bacteria were $140 \pm 6.78$ to $285 \pm 12.36,123 \pm 11.17$ and $38 \pm 0.56 \mu \mathrm{mol} \mathrm{h}^{-1} \mathrm{l}^{-1}$, respectively, and those of free aminopeptidase activity were $83 \pm 6.15$ to $137 \pm 5.83,82 \pm 12.18$ and $8 \pm 0.14 \mu \mathrm{mol} \mathrm{h}^{-1} \mathrm{l}^{-1}$, respectively. J. libera-5(2) did not produce any detectable amounts of total and free aminopeptidase while grazing on Aeromonas, Bacillus and Coryneforms. The chemical characterization of partially purified aminopeptidase of $J$. libera-5(2) produced during grazing on a strain of Pseudomonas sp. indicated the enzyme to be metal-chelater-sensitive alkaline serine aminopeptidase with optimal activity at $\mathrm{pH}$ 8.0 and $30^{\circ} \mathrm{C}$; it was not affected by the major cations of seawater, such as $\mathrm{Na}^{+}, \mathrm{Ca}^{2+}$ and $\mathrm{Mg}^{2+}$. The results suggest that at least some marine HNF may significantly contribute to the enzyme pool in marine environments while selectively grazing on bacteria.
\end{abstract}

KEY WORDS: Aminopeptidase $\cdot$ Grazing $\cdot$ Heterotrophic nanoflagellates $\cdot$ Marine bacteria

\section{INTRODUCTION}

Heterotrophic nanoflagellates (HNF) (2 to $20 \mu \mathrm{m}$ ) are ubiquitous plankton communities in marine environments. Several studies have reported the importance of HNF as the principal grazers of bacteria (reviewed by Sherr \& Sherr 2002) and the influence HNF have on both the size distribution of bacterial communities (Andersen et al. 1986, González et al. 1990) and their taxonomical compositions (Hahn \& Höfle 1998, Jürgens et al. 1999). A substantial part (10 to $50 \%$ ) of primary production is channeled through bacteria (Cole et al. 1988), and the bacteria produced are mostly consumed by HNF that differ in their food selectivity and feeding strategies (Fenchel 1986, Nagata 2000). By repackaging bacterial biomass into cells accessible to larger zooplankton (Sherr et al. 1986), and/or fish larvae (Fukami et al. 1999), these organisms function as intermediates in the transfer of energy to higher trophic levels, and they also act as a catalyst for the remineralization and recycling of elements essential for phytoplankton and microbial growth (Goldman et al. 1985, Porter et al. 1985).

Most of the studies on HNF have been focused on seasonal variation (Fukami et al. 1991, Tanaka \& Taniguchi 1999), quantification of grazing rates on 
bacteria (reviewed by Landry 1994) and distribution of HNF in different aquatic environments (Nagata 1988, Fukami et al. 1996). There are very few studies available on the metabolism of HNF. Previous studies have stressed that grazing by HNF enhances the metabolic activity of bacteria by releasing dissolved organic carbon (Taylor et al. 1985, Pelegrí et al. 1999), dissolved free and combined amino acids (Andersson et al. 1985, Nagata \& Kirchman 1991), dissolved organic phosphorus (Andersen et al. 1986), and colloidal particles (Koike et al. 1990). These released substances are important bacterial substrates and may play a role in the enrichment of the microenvironment (Nagata 2000). However, less attention has been given to the secretion of hydrolytic enzymes. Few studies have reported that, in common with other microorganisms, HNF can also be a novel source of enzymes: acid phosphatase (Nagata \& Kirchman 1992b), acid lysozyme (González et al. 1993), acetylglucosaminidase (Vrba et al. 1993, Simek et al. 1994, Zubkov \& Sleigh 1998, Sherr \& Sherr 1999), $\alpha$-glucosidase and aminopeptidase (Karner et al. 1994).

HNF have been distinguished from other microorganisms present in the marine planktonic food web by an ability to digest bacterial cell walls almost instantly. A large amount of hydrolytic enzymes must be released to perform this digestion during only a short time (Zubkov \& Sleigh 1998). Despite their importance as an enzyme producer, the enzymatic pathways of these organisms are very poorly understood. So far the chemical characterization and ecological implication of these enzymes have not been studied. The enzymatic studies on HNF have been primarily focused on the quantification of either HNF abundance (Simek et al. 1994, Zubkov \& Sleigh 1998) or grazing activity (González et al. 1993, Vrba et al. 1993). However, there is no report available on the correlation of enzyme activity with the qualitative aspects of HNF grazing.

In the present paper we aimed to test the hypothesis that the enzyme levels of HNF are influenced by the qualitatively different food bacterial types. Here, we have taken Jakoba libera-5(2), natural communities of bacteria and 6 bacteria of 5 different taxonomic groups, and aminopeptidase as the model HNF, qualitatively different prey organisms and the hydrolytic enzyme, respectively. Additionally, the partial biochemical characterization of aminopeptidase released by J. libera-5(2) was also investigated.

\section{MATERIALS AND METHODS}

Isolation of HNF and prey bacteria. A strain of HNF was isolated from natural seawater from the Pacific
Ocean, Kochi-ken, Japan, by using seawater medium enriched with rice-grain and serial dilution techniques. It measured 4 to $5 \mu \mathrm{m}$ in length and had a cell volume of $24 \mu^{3}$. This strain was tentatively identified as Jakoba libera strain 5(2) (Ruinen) Patterson (Patterson 1990). The clonal culture of J. libera-5(2) was routinely maintained in rice-grain culture medium. Bacteria present in the rice-grain enrichment culture were considered to be the natural communities of marine bacteria (NCB). Six bacterial strains (Ae-B1, Fl-B1, GPR-2, GPR-3, Ps-B2 and Ps-B6) were also isolated from Pacific Ocean, Kochi-ken, surface seawater samples and were subsequently identified with an array of biochemical tests according to Bergey's Manual of Determinative Bacteriology (Holt et al. 1994). These bacterial strains were tentatively identified as Aeromonas sp. (Ae-B1), Bacillus sp. (GPR-2), Coryneforms (GPR-3), Flavobacterium sp. (Fl-B1) and Pseudomonas sp. (Ps-B2 and Ps-B6).

Bacterial sizes. Bacterial cell size was determined by a computer-assisted image analysis of 4,6-diamidino2-phenylindole (DAPI) stained bacterial cells (Fukami et al. 1991) with an epifluorescence microscope (Olympus BX60) equipped with a charge-coupled device camera (SenSys 400, Photometrics). Length $(L)$ and width $(W)$ were measured from the photographs by using IP Lab Scientific Imaging Software (Scanalytica). Cell volume $(V)$ was calculated as $V=4 / 3\left[\pi(W / 2)^{3}\right]+$ $\left[\pi(W / 2)^{2} \times(L-W)\right]$ (González et al. 1990).

Grazing experiment. The isolated pure culture of bacterial strains were grown in a FeTY medium, consisting of $0.5 \mathrm{~g} \mathrm{l}^{-1}$ trypticase peptone, $0.05 \mathrm{~g} \mathrm{l}^{-1}$ yeast extract, $0.01 \mathrm{~g} \mathrm{l}^{-1}$ ferric citrate and $80 \%$ (v/v) aged seawater at pH 7.5 (Fukami et al. 1992) for $72 \mathrm{~h}$. The bacteria cells were harvested by centrifugation $(5500 \times g$, $30 \mathrm{~min}$ ) at $4^{\circ} \mathrm{C}$. The pellets were washed repeatedly with $0.22 \mu \mathrm{m}$ filtered and autoclaved aged seawater to remove the cultivation medium, and resuspended in $0.22 \mu \mathrm{m}$ filtered and autoclaved aged seawater. Before the grazing experiments were performed, the resuspension of each bacteria was filtered through $0.8 \mu \mathrm{m}$ membrane to remove bacterial aggregates. The natural bacteria present in the culture of HNF were eliminated by stepwise dilution techniques (Pelegrí et al. 1999). The HNF culture with natural prey bacteria was transferred serially by adding $0.1 \mathrm{ml}$ (in the case of prey bacteria Ps-B2, Ps-B6 and Fl-B1) or $1 \mathrm{ml}$ (in the case of prey bacteria Ae-B1, GPR-2 and GPR-3) of HNF culture to $100 \mathrm{ml}$ of the high-density resuspension of axenic culture of each prey bacterium $\left(10^{7}\right.$ cells $\left.\mathrm{ml}^{-1}\right)$. HNF in the inoculated cultures were allowed to grow to stationary phase, which usually occurred 4 to $6 \mathrm{~d}$ after HNF inoculation. The above reinoculation method was repeated several times to obtain an HNFbacterium predator-prey system by successively di- 
luting natural bacteria. In addition, cultures were monitored regularly to assure purity of the prey bacteria by observing the typical rod shape and size (Table 1) with an epifluorescence microscope. No contamination was recorded during the experiment.

Prior to the grazing experiments, HNF were cultured for several generations with monoxenic cultures of 6 individual isolated bacteria as prey. The grazing experiments were conducted in $250 \mathrm{ml}$ screw-cap bottles containing $100 \mathrm{ml}$ of $0.22 \mu \mathrm{m}$ filtered and autoclaved aged seawater ( $\mathrm{pH}$ 8.0). HNF used as inocula were previously cultured on the same bacterial isolate as that used in the grazing experiment. The initial concentrations of HNF set in the growth experiments were $2.0 \times 10^{3}$ cells $\mathrm{ml}^{-1}$. The initial concentrations of prey bacteria ranged from 9.4-10.1 × $10^{6}$ cells $\mathrm{ml}^{-1}$. The natural communities of bacteria were obtained from the flagellate rice-grain culture by filtering through a $0.8 \mu \mathrm{m}$ membrane. More than $98 \%$ of the HNF were removed by this filtration method. Bacteria were harvested from the filtrate by centrifugation $(5500 \times g, 30 \mathrm{~min})$ at $4{ }^{\circ} \mathrm{C}$. After repeated washing with $0.22 \mu \mathrm{m}$ filtered and autoclaved aged seawater, bacterial cells were resuspended in $0.22 \mu \mathrm{m}$ filtered and autoclaved aged seawater with a concentration of 9.4$10.1 \times 10^{6}$ cells $\mathrm{ml}^{-1}$. Bacteria-only controls were also prepared for each bacterium and natural communities of bacteria by adding the initial concentration of individual prey bacterium to the $100 \mathrm{ml}$ of $0.22 \mu \mathrm{m}$ filtered and autoclaved aged seawater $(\mathrm{pH}$ 8.0) in a $250 \mathrm{ml}$ screw-cap bottle. The 6 bacterial strains and natural communities of bacteria did not grow in the bacteriaonly control culture; instead, their cell abundance decreased slightly with time.

Bottles were incubated in the dark at $20^{\circ} \mathrm{C}$ without shaking, and at predetermined intervals the abundances of HNF and bacteria as well as aminopeptidase production rates were determined. Abundances of HNF and bacteria were determined by staining with DAPI (Fukami et al. 1991). A schematic of the grazing experiment is shown in Fig. 1. All the measurements were conducted in triplicate, and data are expressed as means \pm standard deviation.

The net cellular production $\left(10^{4}\right.$ cells $\left.\mathrm{ml}^{-1}\right)$ of $\mathrm{HNF}$ during the grazing experiment was determined by the difference between the highest and initial HNF abundance (Pérez-uz 1996).

Aminopeptidase assay. The aminopeptidase activities in the cell-free filtrate $(0.22 \mu \mathrm{m}$ filtrate) and unfiltered culture of HNF Jakoba libera-5(2) grazing on qualitatively different bacteria (culture of HNF + bacteria) and in the bacteria-only control were measured fluorometrically using 7-l-leucyl-4-methyl-coumarinylamide (Leu-MCA) as substrate (Hoppe 1983). LeuMCA has already been established as a model substrate for aminopeptidase activity in the marine environment (see Patel et al. 2000, and references

Table 1. Characterization of food bacterial strains. Cell size was determined at an early stationary phase

\begin{tabular}{|c|c|c|c|c|}
\hline Name of bacteria & Motility & Length & $\begin{array}{l}\text { Mean } \pm \text { SD }(\mu \mathrm{m}) \\
\text { Width }\end{array}$ & Volume \\
\hline Ps-B2 (Pseudomonas sp.) & + & $1.50 \pm 0.36$ & $0.32 \pm 0.04$ & $0.112 \pm 0.011$ \\
\hline Ps-B6 (Pseudomonas sp.) & + & $1.40 \pm 0.19$ & $0.43 \pm 0.06$ & $0.183 \pm 0.032$ \\
\hline Fl-B1 (Flavobacterium sp.) & + & $1.33 \pm 0.13$ & $0.30 \pm 0.03$ & $0.087 \pm 0.026$ \\
\hline Ae-B1 (Aeromonas sp.) & + & $1.05 \pm 0.34$ & $0.28 \pm 0.02$ & $0.058 \pm 0.021$ \\
\hline GPR-2 (Bacillus sp.) & + & $1.66 \pm 0.64$ & $0.40 \pm 0.05$ & $0.191 \pm 0.046$ \\
\hline GPR-3 (Coryneforms) & + & $1.60 \pm 0.17$ & $0.45 \pm 0.08$ & $0.231 \pm 0.062$ \\
\hline
\end{tabular}

Preparation of food bacteria
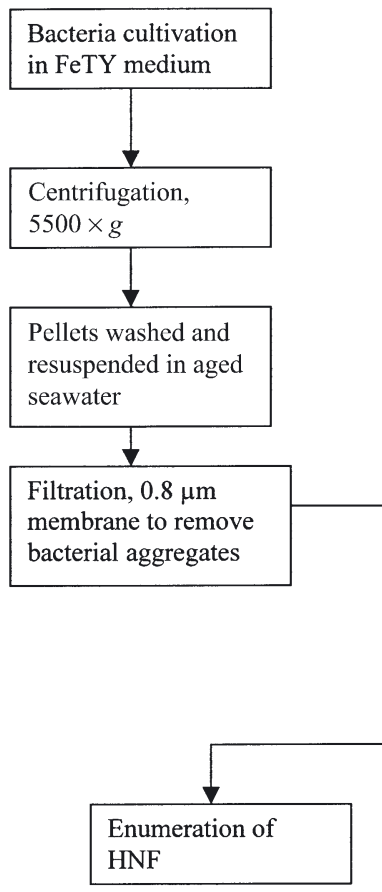

Fig. 1. Schematic of the experiment: HNF grazing on different food bacteria

\section{Grazing experiment Preparation of NCB}

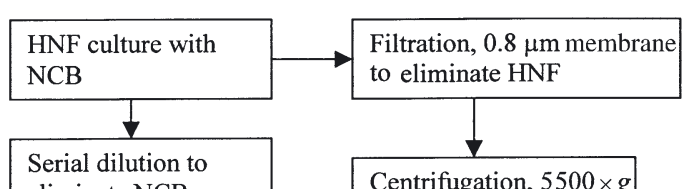

eliminate NCB to obtain NCB

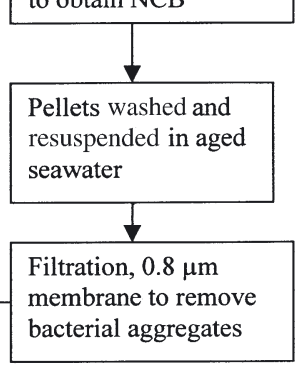

Sub-sampling at

predetermined time

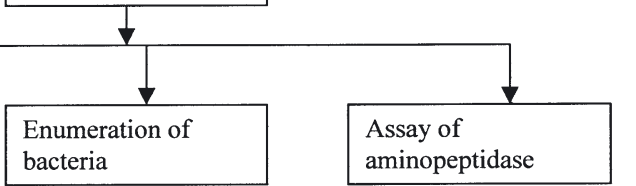

bacterium predatorprey system
(Pelegrí et al. 1999) 
cited therein). The activity in the cell-free $0.22 \mu \mathrm{m}$ filtrate was referred to as the free enzyme activity, and that in the unfiltered sample as the total enzyme activity. The cell-free filtrate was prepared by gently filtering the sample through a $0.22 \mu \mathrm{m}$ Millipore filter (Millipore) with a syringe. The assay mixture was composed of a $0.25 \mathrm{ml}$ subsample of culture filtrate or the unfiltered culture of HNF + bacteria, $4.25 \mathrm{ml}$ of $10 \mathrm{mmol} \mathrm{l}^{-1}$ Tris-HCl buffer $(\mathrm{pH} 8.0)$ and $0.5 \mathrm{ml}$ of $0.5 \mathrm{mmol} \mathrm{l}^{-1}$ Leu-MCA (dissolved in dimethylsulphoxide). The final concentration of Leu-MCA in the assay mixture was $50 \mu \mathrm{mol} \mathrm{l}^{-1}$. This concentration was found to produce the highest rate of hydrolysis in the preliminary kinetic experiment. The assay mixture was incubated at $30^{\circ} \mathrm{C}$ for $1 \mathrm{~h}$. Fluorescence intensity was measured before and after a $1 \mathrm{~h}$ incubation. In the case of total enzyme activity, the assay mixture was filtered using the syringe filtration method as above, and then the fluorescence intensity of the filtrate was measured. The fluorescence intensity was determined at wavelengths of $365 \mathrm{~nm}$ for excitation and $440 \mathrm{~nm}$ for emission (Shimadzu RF-500 spectrofluorophotometer). Blanks with $0.22 \mu \mathrm{m}$ filtered and autoclaved aged seawater samples were processed in parallel. After correction of the fluorescence through the blanks, the catalytic activity was estimated from fluorescence of standard 7-amino-4-methylcoumarin (AMC). One unit of enzyme activity was expressed as $\mu \mathrm{mol}$ of AMC produced from the hydrolysis of Leu-MCA per hour per liter of sample under the experimental conditions.

In the case of the bacteria-only culture, both the free and total enzyme activities were determined as mentioned above.

Preparation of aminopeptidase for biochemical characterization. Because of the highest enzymatic activity and net cellular production of HNF Jakoba libera-5(2) with the food bacteria Pseudomonas sp. (Ps-B2), the aminopeptidase of the culture filtrate (0.22 $\mu \mathrm{m}$ filtrate) of HNF grazing on Pseudomonas sp. (Ps-B2) was partially purified and characterized. The cell-free filtrate $(0.22 \mu \mathrm{m}$ filtrate) of the $5 \mathrm{~d}$ old culture of HNF grazing on bacteria (culture of HNF + Ps-B2) was treated as a crude enzyme preparation. The enzyme in the crude preparation was precipitated with $80 \%$ (w/v) ammonium sulphate. The precipitate was collected by centrifugation $(5500 \times g, 30 \mathrm{~min})$ at $4{ }^{\circ} \mathrm{C}$, then dissolved in $10 \mathrm{mmol}^{-1}$ Tris- $\mathrm{HCl}$ buffer $(\mathrm{pH}$ 7.2) followed by dialysis (molecular weight cut off $15 \mathrm{kd}$ ) for $24 \mathrm{~h}$ at $4^{\circ} \mathrm{C}$ against the same buffer. The dialyzates were pooled and used for further studies.

Effect of $\mathbf{p H}$ and temperature. The $\mathrm{pH}$-dependent activity of partially purified aminopeptidase was examined using the wide range of buffer systems containing $10 \mathrm{mmol} \mathrm{l}^{-1}$ citrate ( $\mathrm{pH} 3.0$ to 6.0), phosphate ( $\mathrm{pH}$ 7.0), Tris-HCl (pH 8.0), borax- $\mathrm{NaOH}(\mathrm{pH} 9.0$ to
10.0) and glycine- $\mathrm{NaOH}$ (pH 11.0 to 12.0). The assay conditions were the same as described above, except buffers of different $\mathrm{pH}$ (3.0 to 12.0) were used for the assay mixture. The effect of temperature on enzyme activity was evaluated by incubating the assay mixture at different temperature $\left(5\right.$ to $60^{\circ} \mathrm{C}$ at $5^{\circ} \mathrm{C}$ increments) for $1 \mathrm{~h}$. To study the heat stability of the enzyme, substrate-free enzyme solutions were held at various temperature $\left(5\right.$ to $60^{\circ} \mathrm{C}$ at $5^{\circ} \mathrm{C}$ increments) for $30 \mathrm{~min}$, followed by cooling to $0^{\circ} \mathrm{C}$ before addition of the assay mixture.

Effect of metal ions and inhibitors. The enzyme was pre-incubated with individual metal ions and inhibitors at $20^{\circ} \mathrm{C}$ for $5 \mathrm{~min}$. Separate blanks with individual metal ions and inhibitors were prepared. The residual activity was measured.

\section{RESULTS}

The isolated HNF Jakoba libera-5(2) was subjected to batch culture grazing experiments with $\mathrm{NCB}$, and 6 bacterial strains of 5 different taxonomic groupsPseudomonas spp. (Ps-B2 and Ps-B6), Flavobacterium sp. (Fl-B1), Aeromonas sp. (Ae-B1), Bacillus sp. (GPR-2) and Coryneforms (GPR-3) - as prey. The abundance of $J$. libera-5(2) varied with the types of prey bacteria. J. libera-5(2) had its highest abundance of $9.83( \pm 0.58) \times 10^{4}$ cells $\mathrm{ml}^{-1}$ with the prey bacteria Ps-B2 (Fig. 2A), followed by $6.61( \pm 1.26) \times 10^{4}$ cells $\mathrm{ml}^{-1}$ with Ps-B6 (Fig. 3A), $4.20( \pm 0.97) \times 10^{4}$ cells ml $^{-1}$ with Fl-B1 (Fig. 4A) and $2.63( \pm 0.81) \times 10^{4}$ cells ml $^{-1}$ with NCB (Fig. 5A). J. libera-5(2) did not grow (HNF abundance ca. $0.22 \times 10^{4}$ cells $\mathrm{ml}^{-1}$ ) with the prey bacteria Ae-B1, GPR-2 and GPR-3. Generally with the appearance of HNF in the cultures of Pseudomonas spp. (Ps-B2 and Ps-B6), Flavobacterium sp. (Fl-B1) and natural communities of bacteria (NCB) resulted in a sharp decline in bacterial numbers (58-72, 46 and $33 \%$ of the control, respectively) parallel to an increase in both free and total aminopeptidase activity (Figs. 2B, $3 \mathrm{~B}, 4 \mathrm{~B} \& 5 \mathrm{C})$.

In the bacteria-only control of NCB, the aminopeptidase activity (free and total) was stable and roughly followed the bacterial density (Fig. 5B). After the inoculation of HNF, the free and total aminopeptidase activities increased 12- and 15-fold, respectively (Fig. 5C).

In Ps-B2, Ps-B6 and Fl-B1, the total aminopeptidase of HNF followed the trend in HNF abundance and reached its highest value at Day $5(285 \pm 12.36 \mu \mathrm{mol}$ $\mathrm{h}^{-1} \mathrm{l}^{-1}$, Fig 2B), Day $6\left(140 \pm 6.78 \mu \mathrm{mol} \mathrm{h}^{-1} \mathrm{l}^{-1}\right.$, Fig. 3B) and Day $6\left(123 \pm 11.17 \mu \mathrm{mol} \mathrm{h}^{-1} \mathrm{l}^{-1}\right.$, Fig. 4B), respectively. The free enzymes of HNF with Ps-B2, Ps-B6 and Fl-B1 as prey reached a stationary phase after 3 to $5 \mathrm{~d}$ of HNF addition, and yielded the highest value $137 \pm$ 

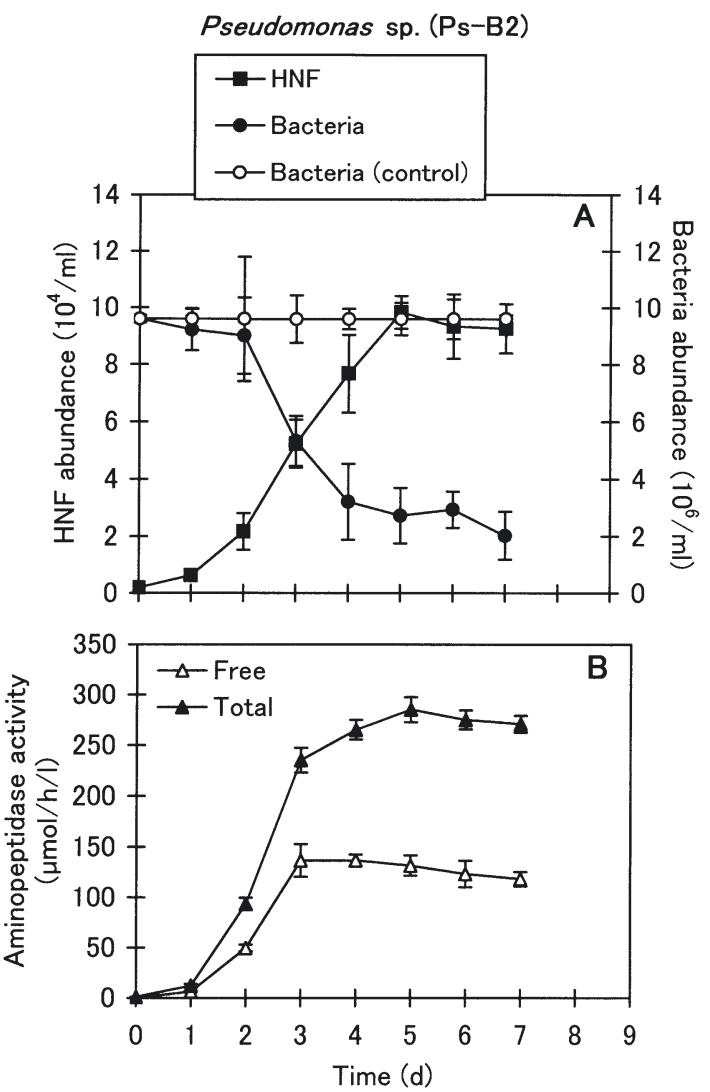

Fig. 2. Batch culture of heterotrophic nanoflagellates Jakoba libera-5(2) with Pseudomonas species (Ps-B2) as prey. (A) HNF and bacterial abundance, and (B) free and total aminopeptidase activity produced by HNF J. libera-5(2). Error bars are SD of triplicate measurements. SD are given when they exceed dimension of the symbols

$5.83 \mu \mathrm{mol} \mathrm{h}^{-1} \mathrm{l}^{-1}$ at Day $4,83 \pm 6.15 \mu \mathrm{mol} \mathrm{h}^{-1} \mathrm{l}^{-1}$ at Day 5 and $82 \pm 12.18 \mu \mathrm{mol} \mathrm{h}^{-1} \mathrm{l}^{-1}$ at Day 6 , respectively. The HNF Jakoba libera-5(2) did not produce any measurable amounts of free and total aminopeptidase with Ae-B1, GPR-2 and GPR-3 as prey bacteria, but some total aminopeptidase always appeared in all predatorprey systems after HNF inoculation. In contrast, aminopetidase activity was not detected in the axenic culture of 6 food bacterial (Ps-B2, Ps-B6, Fl-B1, Ae-B1, GPR-2 and GPR-3) strains when cultivated with aged seawater, FeTY medium (data not shown) and $0.8 \mu \mathrm{m}$ culture filtrate of HNF (previously grown on the same bacterial strain) (data not shown). As aminopeptidase was absent in both nutrient-depleted aged seawater, and nutrient-rich (FeTY and $0.8 \mu \mathrm{m}$ culture filtrate of HNF) medium, nutrient-depleted aged seawater medium was used in the grazing response of HNF on different food bacteria because of its advantage in minimizing the changes in food bacterial concentration by not supporting bacterial growth (Eccleston-Parry \& Leadbeater 1994, Zubkov \& Sleigh 2000).
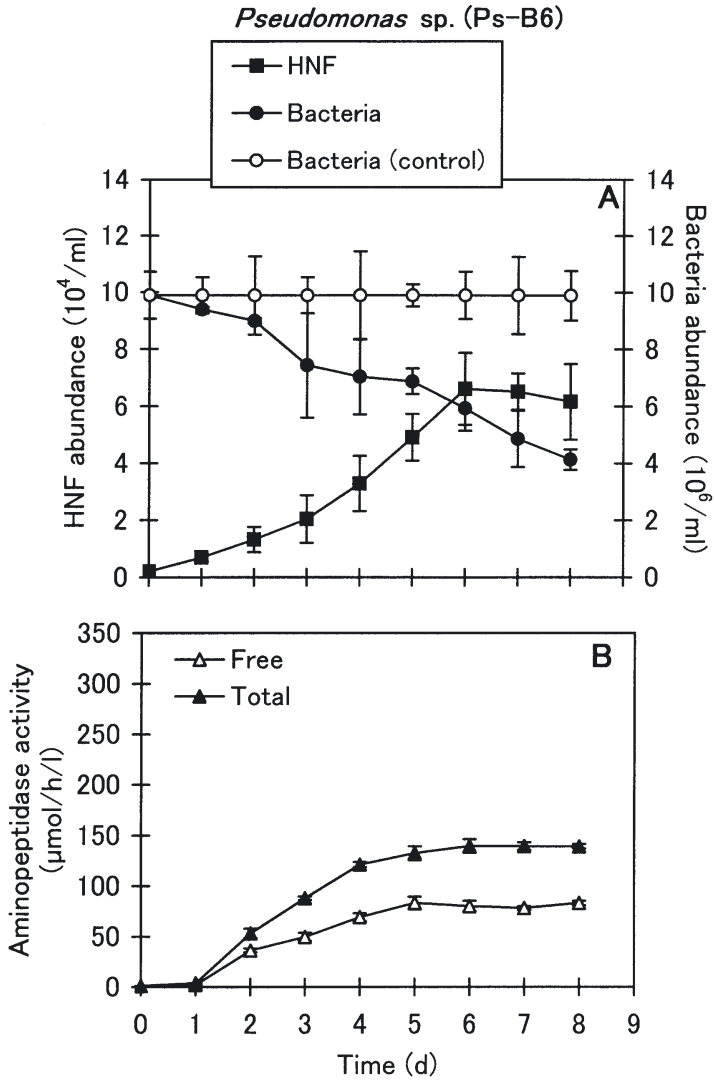

Fig. 3. Batch culture of heterotrophic nanoflagellates Jakoba libera-5(2) with Pseudomonas species (Ps-B6) as prey. (A) HNF and bacterial abundance, and (B) free and total aminopeptidase activity produced by HNF J. libera-5(2). Error bars are SD of triplicate measurements. SD are given when they exceed dimension of the symbols

We partially purified and characterized the free aminopeptidase of Jakoba libera-5(2) + Ps-B2 as prey bacteria because of the highest enzymatic activity and cell abundance of the HNF. The optimum $\mathrm{pH}$ of the partially purified enzyme was 8.0 (Fig. 6). At pH 9.0 and $10.0,72$ and $26 \%$ of the maximum enzyme activity retention was observed. The effect of temperature on enzyme activity and stability is shown in Fig. 7. The highest activity was observed at $30^{\circ} \mathrm{C}$. The enzyme activity sharply decreased above $30^{\circ} \mathrm{C}$. The relative activity at $40^{\circ} \mathrm{C}$ was $41 \%$. The aminopeptidase was inactivated by exposure to a temperature of $45^{\circ} \mathrm{C}$ for $30 \mathrm{~min}$. Taking the results in these experiment, together, it is concluded that this enzyme is relatively heat-labile. Addition of calcium did not stabilize the enzyme activity under high temperature. The partially purified aminopeptidase was unaffected by the major cations of seawater, such as $\mathrm{Na}^{+}, \mathrm{Ca}^{2+}$ and $\mathrm{Mg}^{2+}$, even at a higher concentration $\left(10 \mathrm{mmol} \mathrm{l}^{-1}\right)$ (Table 2). However, the activity was suppressed by $\mathrm{Co}^{2+}, \mathrm{Cu}^{2+}, \mathrm{Hg}^{2+}, \mathrm{Mn}^{2+}$ and $\mathrm{Zn}^{2+}$ at 1 mmol $1^{-1}$. Metal protease inhibitors (EDTA and or- 

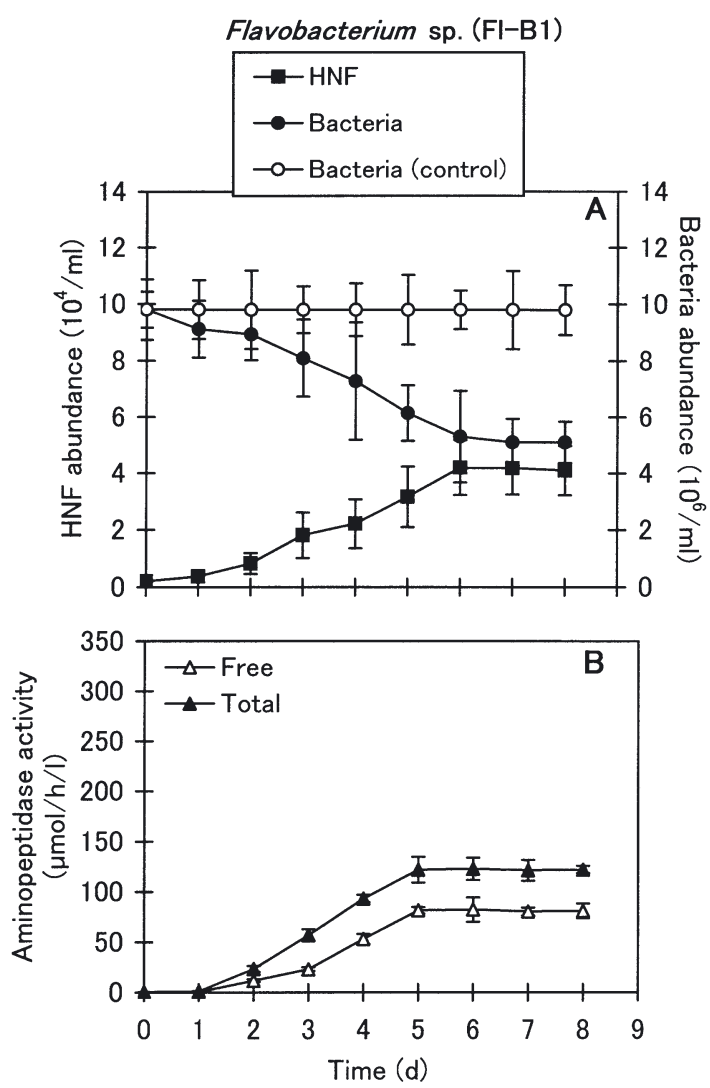

Fig. 4. Batch culture of heterotrophic nanoflagellates Jakoba libera-5(2) with Flavobacterium species (Fl-B1) as prey. (A) HNF and bacterial abundance, and (B) free and total aminopeptidase activity produced by HNF J. libera-5(2). Error bars are SD of triplicate measurements. SD are given when they exceed dimension of the symbols

thophenanthroline) strongly inhibited activity, suggesting that aminopeptidase requires metal ions for the catalysis. This enzyme was also inhibited by thiol protease inhibitor (parachloromercuribenzoic acid, iodoacetic acid and iodoacetamide), indicating the involvement of a sulphhydryl group at the active site of the enzyme. Moreover, the $\mathrm{pH}$ profile of the enzyme and its inhibition by serine protease inhibitors (leupeptin and phenylmethylsulphonyl fluoride) indicate this enzyme to be an alkaline serine aminopeptidase.

\section{DISCUSSION}

Batch culture grazing experiments are the convenient way of examining HNF behavior in the presence of different prey organisms. They are relatively quick and simple, and they generate useful growth kinetic data to measure bacterivory (Fenchel 1982, EcclestonParry \& Leadbeater 1994). The drawback of batch cul-
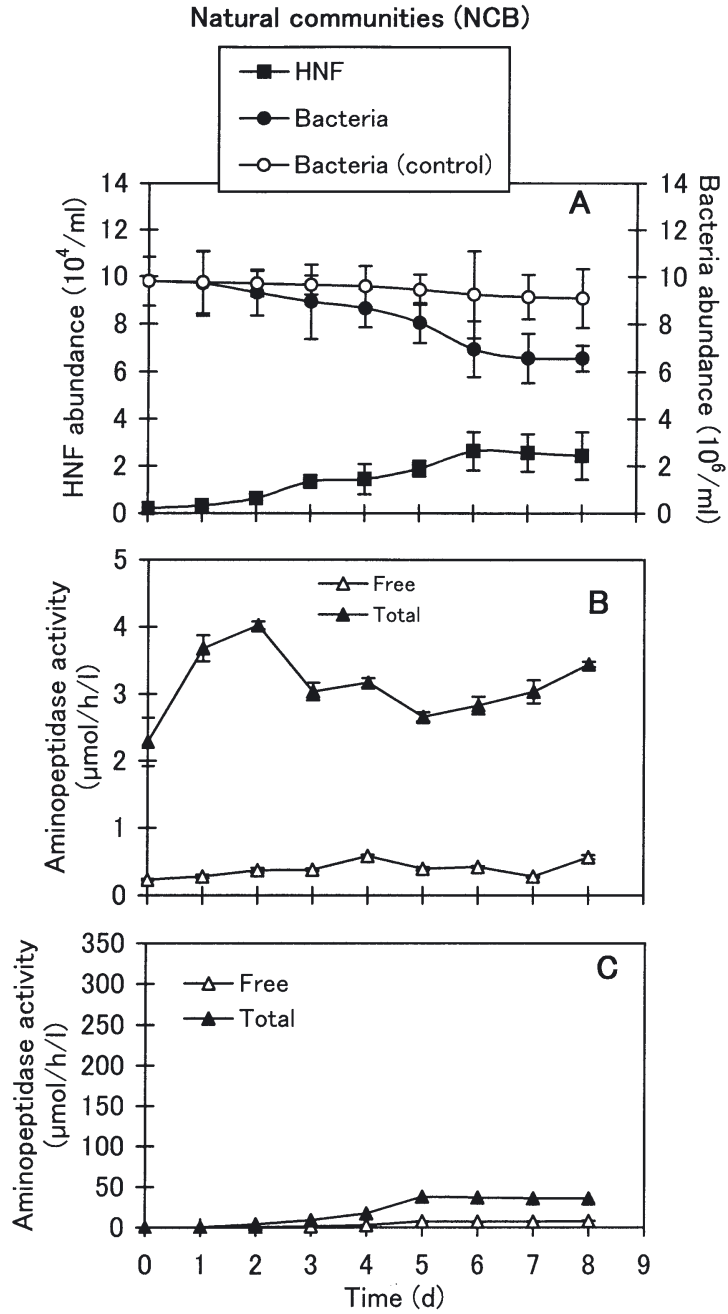

Fig. 5. Batch culture of heterotrophic nanoflagellates Jakoba libera-5(2) with natural communities of bacteria (NCB) as prey. (A) HNF and bacterial abundance, (B) free and total aminopeptidase activity of $\mathrm{NCB}$, and (C) free and total aminopeptidase activity produced by HNF J. libera-5(2). Error bars are SD of triplicate measurements. SD are given when they exceed dimension of the symbols. Note that the enzyme activity has different scales in (B) and (C)

ture is that the prey bacteria are initially abundant and then their density can be rapidly decreased due to predation by HNF. However, these pulsed prey grazing experiments may be better mimics of the natural prey environment encountered by HNF than continuous culture experiments. Pelagic HNF encounter locally enriched patches of prey in the sea, more often in the form of marine snow (Azam \& Long 2001). The ability of HNF to locate prey by chemosensing (Sibbald et al. 1987) and to rapidly synthesize food vacuoles and increase cell volume when exposed to abundant prey appears to be an adaptation used to exploit temporary 


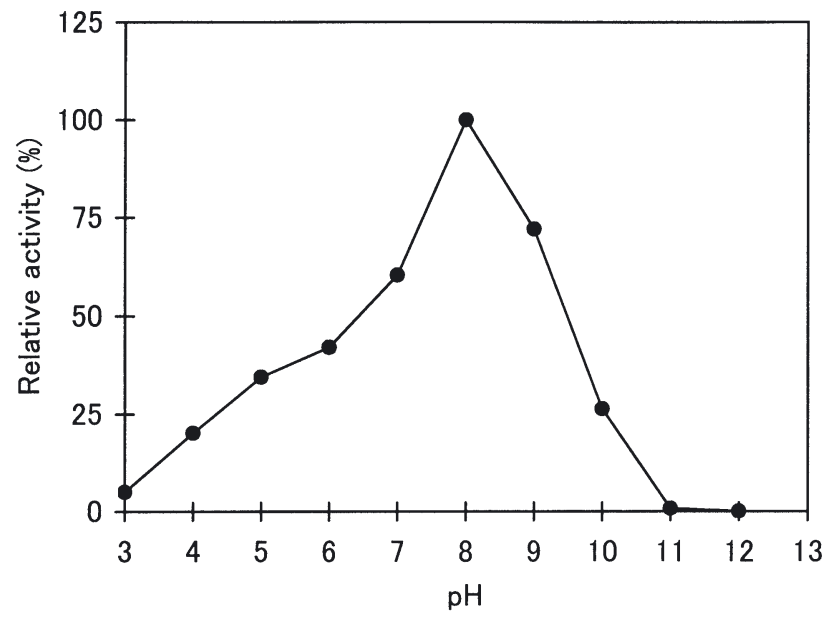

Fig. 6. Effect of $\mathrm{pH}$ on partially purified free aminopeptidase activity of Jakoba libera-5(2) with Pseudomonas sp. (Ps-B2) as prey bacteria. The buffers used were $10 \mathrm{mmol} \mathrm{l}^{-1}$ citrate (pH 3.0-6.0), phosphate (pH 7.0), Tris-HCl (8.0), borax- $\mathrm{NaOH}$ (pH 9.0-10.0) and glycine-NaOH (pH 11.0-12.0)

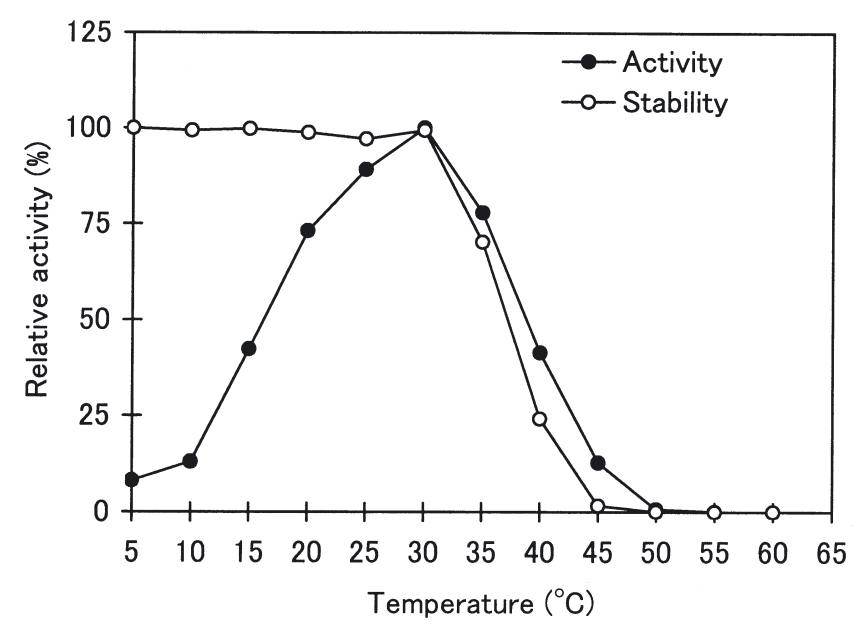

Fig. 7. Effect of temperature on the partially purified free aminopeptidase activity of Jakoba libera-5(2) with Pseudomonas sp. (Ps-B2) as prey bacteria

enriched microenvironments rather than a continuous steady-state prey supply.

Previous reports have suggested that the aminopeptidase activity, which was ubiquitous in marine environments and responsible for catalyzing the peptide bonds, was mostly bound to the bacterial cell membrane (Rosso \& Azam 1987), and heterotrophic bacteria are usually the sole producers of it (Chróst 1990). As to the optimal activity (pH 8.0 to 9.0) (Fig. 6) and thermostability (below $30^{\circ} \mathrm{C}$ ) (Fig. 7), the aminopeptidase of Jakoba libera-5(2) is able to function in the enzyme catalyzed organic matter cycling in marine environment. Furthermore, they might be responsible for the 'hyperproduction of enzyme' in organic aggregates,
Table 2. Effect of metal ions and inhibitors on aminopeptidase activity. The activity is expressed as a percentage of the activity in the absence of metal ion and inhibitor. The partially purified enzyme solution was pre-incubated with the individual metal ion and inhibitor at $20^{\circ} \mathrm{C}$ for $5 \mathrm{~min}$. Separate blanks with individual metal ions and inhibitors were prepared. PCMB: para-chloromercuribenzoic acid. PMSF: phenylmethylsulphonyl fluoride

\begin{tabular}{|lccc|}
\hline \multirow{2}{*}{$\begin{array}{l}\text { Metal ions and } \\
\text { inhibitors }\end{array}$} & \multicolumn{3}{c|}{ Concentration $\left(\mathrm{mmol} \mathrm{l}^{-1}\right)$} \\
& 0.1 & 1 & 10 \\
\hline $\mathrm{Ca}^{2+}$ & 100 & 100 & 100 \\
$\mathrm{Co}^{2+}$ & 43 & 22 & 13 \\
$\mathrm{Cu}^{2+}$ & 0 & 0 & 0 \\
$\mathrm{Hg}^{2+}$ & 0 & 0 & 0 \\
$\mathrm{Mg}^{2+}$ & 100 & 100 & 100 \\
$\mathrm{Mn}^{2+}$ & 83 & 47 & 22 \\
$\mathrm{Na}^{+}$ & 100 & 100 & 100 \\
$\mathrm{Zn}^{2+}$ & 56 & 43 & 30 \\
EDTA & 3 & 1 & 0 \\
Iodoacetic acid & 13 & 9 & 0 \\
lodoacetamide & 21 & 11 & 6 \\
Leupeptin & 0 & 0 & 0 \\
Orthophenanthroline & 10 & 4 & 0 \\
PCMB & 1 & 0 & 0 \\
PMSF & 6 & 3 & 0 \\
\hline
\end{tabular}

where they densely colonize, along with the attached bacteria (Cho \& Azam 1988).

The functionally active hydrolytic enzymes are synthesized by HNF and secreted into pinocytosis vesicles or food vacuoles of HNF (Chróst 1990); release of extracellular enzymes from living HNF cells has also been reported (Nagata \& Kirchman 1992b, Vrba et al. 1993, Simek et al. 1994). Although little is known about the enzyme production mechanisms of HNF, Nagata \& Kirchman (1992b) hypothesized that HNF released digestive enzymes, which are embedded inside the partially digested bacterial cell walls, probably as a function of egestion. The ecological implication of these enzymes is still unknown. They have pH optima clearly different from bacterial prey mediated enzymes. Karner et al. (1994) observed the accumulation of aminopeptidase activity ( $\mathrm{pH}$ optimum at $\mathrm{pH}$ of natural seawater) in a culture medium of natural communities of HNF fed on either live or heat-killed bacteria of natural assemblages of marine bacteria. However, our results showed that the release of aminopeptidase (both free and total) by Jakoba libera-5(2) as measured at $\mathrm{pH} 8.0$ with a fluorogenic substrate can be greatly influenced by the prey bacteria. J. libera5(2) produced aminopeptidase while grazing on Pseudomonas spp. (Ps-B2 and Ps-B6) (Figs. 2B \& 3B), Flavobacterium sp. (Fl-B1) (Fig. 4B) and NCB (Fig. 5C). There was no enzyme activity detected with Aeromonas (Ae-B1), Bacillus (GPR-2) and Coryneforms (GPR-3). 
Table 3. Net cellular production and ranges of total and free aminopeptidase activity of HNF Jakoba libera-5(2) fed with qualitatively different food bacteria. The net cellular production of HNF during the grazing experiment was determined by the difference between the highest and the initial HNF abundances. Each range represents the minimum and maximum of the enzyme activity that occurred during the batch culture grazing experiment

\begin{tabular}{|lccc|}
\hline Bacteria & $\begin{array}{c}\text { Net cellular } \\
\text { production } \\
\left(10^{4} \text { HNF cells ml }{ }^{-1}\right)\end{array}$ & $\begin{array}{c}\text { Range of total amino- } \\
\text { peptidase activity } \\
\left(\mu \mathrm{mol} \mathrm{h} \mathrm{h}^{-1}\right)\end{array}$ & $\begin{array}{c}\text { Range of free } \\
\text { aminopepti- } \\
\text { dase activity } \\
\left(\mu \mathrm{mol} \mathrm{h}^{-1} \mathrm{l}^{-1}\right)\end{array}$ \\
\hline Ps-B2 & $9.63 \pm 1.30$ & $1.2-285$ & $0.1-137$ \\
Ps-B6 & $6.41 \pm 1.87$ & $1.1-140$ & $0.3-83$ \\
Fl-B1 & $4.0 \pm 0.29$ & $0.6-123$ & $0.1-82$ \\
NCB & $2.43 \pm 0.083$ & $0.1-38$ & $0.04-8.6$ \\
Ae-B1 & $0.019 \pm 0.005$ & $0-0.4$ & $0-0.2$ \\
GPR-2 & $0.017 \pm 0.006$ & $0-0.2$ & $0-0.1$ \\
GPR-3 & $0.015 \pm 0.0 .005$ & $0-0.3$ & $0-0.1$ \\
\hline
\end{tabular}

The role of alkaline serine aminopeptidase released by Jakoba libera-5(2) in feeding processes is still unknown, we speculate that because some HNF graze on attached bacteria (Caron 1987, Zubkov \& Sleigh 2000) the secretion of aminopeptidase by HNF could be important in the production of dissolved free amino acids by hydrolysis of proteins from organic aggregates and detritus that may nurture the preferred bacterial growth (Nagata \& Kirchman 1992a). In organic nutrientdepleted oceanic waters, perhaps certain individual amino acids, especially serine, or a combination of amino acids, which have been known as a potential attractant for bacteria (Adler 1966,

The 6 qualitatively different prey bacteria used in this study did not produce aminopeptidase when axenically cultured in nutrient-depleted aged seawater and a nutrient-rich (FeTY and $0.8 \mu \mathrm{m}$ culture filtrate of HNF) medium. Overall, the production mechanisms of aminopeptidase by aquatic bacteria are poorly understood because of the complexity of proteolytic enzymatic systems (Chróst 1991, Mohapatra et al. 2003). Chróst (1990) mentioned that some aquatic bacteria control the regulation of enzyme synthesis that largely depends on the physico-chemical conditions of the surrounding habitat. Non-detection of aminopeptidase activity in these 6 qualitatively different prey bacterial strains might be due to the repression of enzyme synthesis by chemical constituents of the cultivation medium, and/or the growth conditions used in this study.

The production rate of aminopeptidase of Jakoba libera-5(2) was directly proportional to the net cellular production of HNF (Table 3). These results indicate that among the different qualitative food bacterial strains tested, were the most palatable food for J. liberia-5(2) Pseudomonas spp. (Ps-B2 and Ps-B6), followed by Flavobacterium sp. (Fl-B1) and natural communities of bacteria (NCB). They did not like Aeromonas (Ae-B1), Bacillus (GPR-2) and Coryneforms (GPR-3) as food. When our results are compared with those of Karner et al. (1994), the variation in results might be attributed to the phenotypic traits of bacteria and HNF, and/or the environmental parameters. Earlier reports mostly presented data on the quantitative relationship of abundance, and/or bacterivory of HNF with extracellular enzyme activity of HNF (Vrba et al. 1993, Simek et al. 1994, Zubkov \& Sleigh 1998). To our knowledge, this is the first report to correlate HNF enzyme activity with qualitative aspects of HNF grazing.
1975), produced during the hydrolysis of proteins in the water column may function as a chemical signal by the flagellate to attract and/or nurture the prey bacteria (Andersson et al. 1985). To understand fully the nature and properties of this enzyme in ecological processes, it is essential to isolate, purify and characterize it to a greater extent.

Acknowledgements. The authors would like to thank $\mathrm{T}$. Nishizima and M. Adachi for suggestions and N. Yoshimoto for helping in field studies.

\section{LITERATURE CITED}

Adler J (1966) Chemotaxis in bacteria. Science 153:708-716 Adler J (1975) Chemotaxis in bacteria. Annu Rev Biochem 44: 341-366

Andersen OK, Goldman JC, Caron DA, Dennett MR (1986) Nutrient cycling in a microflagellate food chain. III. Phosphorus dynamics. Mar Ecol Prog Ser 31:47-55

Andersson A, Lee C, Azam F, Hagström ^̊ (1985) Release of amino acids and inorganic nutrients by heterotrophic marine microflagellates. Mar Ecol Prog Ser 23:99-106

Azam F, Long RA (2001) Sea snow microcosms. Nature 414: 495-498

Caron DA (1987) Grazing of attached bacteria by heterotrophic microflagellates. Microb Ecol 13:203-218

Cho BC, Azam F (1988) Major role of bacteria in biogeochemical fluxes in the ocean's interior. Nature 332:441-443

Chróst RJ (1990) Microbial ectoenzymes in aquatic environments. In: Overbeck J, Chróst RJ (eds) Aquatic microbial ecology: biochemical and molecular approaches. Springer-Verlag, New York, p 47-78

Chróst RJ (1991) Environmental control of the synthesis and activity of aquatic microbial ectoenzymes. In: Chróst RJ (ed) Microbial enzymes in aquatic environments. SpringerVerlag, New York, p 29-59

Cole JJ, Findlay S, Pace ML (1988) Bacterial production in fresh and saltwater ecosystems: a cross-system overview. Mar Ecol Prog Ser 43:1-10

Eccleston-Parry JD, Leadbeater BSC (1994) A comparison of the growth kinetics of six marine heterotrophic nanoflag- 
ellates fed with one bacterial species. Mar Ecol Prog Ser 105:167-177

Fenchel T (1982) Ecology of heterotrophic microflagellates. II. Bioenergetics and growth. Mar Ecol Prog Ser 8:225-231

Fenchel T (1986) The ecology of heterotrophic microflagellates. In: Marshall KC (ed) Advances in microbial ecology, Vol 9. Plenum Press, New York, p 57-97

Fukami K, Meier B, Overbeck J (1991) Vertical and temporal changes in bacterial production and its consumption by heterotrophic nanoflagellates in a north German eutrophic lake. Arch Hydrobiol 122:129-145

Fukami K, Nishijima T, Hata Y (1992) Availability of deep seawater and effects of bacteria isolated from deep seawater on the mass culture of food microalga Chaetoceros ceratosporum. Nippon Suisan Gakkaishi 58:931-936

Fukami K, Murata N, Morio Y, Nishijima T (1996) Distribution of heterotrophic nanoflagellates and their importance as the bacterial consumer in a eutrophic coastal seawater. J Oceanogr 52:399-407

Fukami K, Watanabe A, Fujita S, Yamaoka K, Nishijima T (1999) Predation on naked protozoan microzooplankton by fish larvae. Mar Ecol Prog Ser 185:285-291

Goldman JC, Caron DA, Andersen OK, Dennett MR (1985) Nutrient cycling in a microflagellate food chain. I. Nitrogen dynamics. Mar Ecol Prog Ser 24:231-242

González JM, Sherr EB, Sherr BF (1990) Size-selective grazing on bacteria by natural assemblages of estuarine flagellates and ciliates. Appl Environ Microbiol 56:583-589

González JM, Sherr BF, Sherr EB (1993) Digestive enzyme activity as a quantitative measure of protistan grazing: the acid lysozyme assay for bacterivory. Mar Ecol Prog Ser 100:197-206

Hahn MW, Höfle MG (1998) Grazing pressure by a bacterivorous flagellate reverses the relative abundance of Comamonas acidovorans PX 54 and Vibrio strain CB5 in chemostat cocultures. Appl Environ Microbiol 64:1910-1918

Holt JG, Krieg NR, Sneath PHA, Staley JT, Williams ST (1994) Bergey's manual of determinative bacteriology, 9th edn. Williams \& Wilkins, Hagerstown, MD

Hoppe HG (1983) Significance of exoenzymatic activities in the ecology of brackish water: measurements by means of methylumbelliferyl-substrates. Mar Ecol Prog Ser 11: 299-308

Jürgens K, Pernthaler J, Schalla S, Amann R (1999) Morphological and compositional changes in planktonic bacterial community in response to enhanced protozoan grazing. Appl Environ Microbiol 65:1241-1250

Karner M, Ferrier-Pagès C, Rassoulzadegan F (1994) Phagotrophic nanoflagellates contribute to occurrence of $\alpha$-glucosidase and aminopeptidase in marine environments. Mar Ecol Prog Ser 114:237-244

Koike I, Hara S, Terauchi K, Kogure K (1990) Role of submicrometer particles in the ocean. Nature 345:242-244

Landry MR (1994) Methods and controls for measuring the grazing impact of planktonic protists. Mar Microb Food Webs 8:37-57

Mohapatra BR, Bapuji M, Sree A (2003) Production of industrial enzymes (amylase, carboxymethylcellulase and protease) by bacteria isolated from marine sedentary organisms. Acta Biotechnol 23:75-84

Nagata T (1988) The microflagellate-picoplankton food linkage in the water column of lake Biwa. Limnol Oceanogr 33:504-517

Editorial responsibility: Fereidoun Rassoulzadegan,

Villefranche-sur-Mer, France
Nagata T (2000) Production mechanisms of dissolved organic matter. In: Kirchman DL (ed) Microbial ecology of the oceans. Wiley-Liss, New York, p 121-152

Nagata T, Kirchman DL (1991) Release of dissolved free and combined amino acids by bacterivorous marine flagellates. Limnol Oceanogr 36:433-443

Nagata T, Kirchman DL (1992a) Release of dissolved organic matter by heterotrophic protozoa: implications for microbial food webs. Arch Hydrobiol Beih Ergebn Limnol 35:99-109

Nagata T, Kirchman DL (1992b) Release of macromolecular organic complexes by heterotrophic marine flagellates. Mar Ecol Prog Ser 83:233-240

Patel AB, Fukami K, Nishijima T (2000) Regulation of seasonal variability of aminopeptidase activities in surface and bottom waters of Uranouchi inlet, Japan. Aquat Microb Ecol 21:139-149

Patterson DJ (1990) Jakoba libera (Ruinen, 1938) a heterotrophic flagellate from deep oceanic sediments. J Mar Biol Assoc UK 70:381-393

Pelegrí SP, Christaki U, Dolan J, Rassoulzadegan F (1999) Particulate and dissolved organic carbon production by the heterotrophic nanoflagellate Pteridomonas danica Patterson and Fenchel. Microb Ecol 37:276-284

Pérez-uz B (1996) Bacterial preferences and growth kinetic variation in Uronema marinum and Uronema nigricans (Ciliophora: Scuticociliatida). Microb Ecol 31:189-198

Porter KG, Sherr EB, Sherr BF, Pace M, Sanders RW (1985) Protozoa in planktonic food webs. J Protozool 32:409-415

Rosso AL, Azam F (1987) Proteolytic activity in coastal oceanic waters: depth distribution and relationship to bacterial populations. Mar Ecol Prog Ser 41:231-240

Sherr EB, Sherr BF (1999) $\beta$-Glucosaminidase activity in marine microbes. FEMS Microbiol Ecol 28:111-119

Sherr EB, Sherr BF (2002) Phagotrophy in aquatic microbial food webs. In: Newell S (ed) Manual of environmental microbiology II. ASM Press, Washington, DC, p 409-418

Sherr EB, Sherr BF, Paffenhofer GA (1986) Phagotrophic protozoa as food for metazoans: a 'missing' trophic link in marine pelagic food webs? Mar Microb Food Webs 1:61-80

Sibbald MJ, Albright LJ, Sibbald PR (1987) Chemosensory responses of a heterotrophic microflagellate to bacteria and several nitrogen compounds. Mar Ecol Prog Ser 36: 201-204

Simek K, Vrba J, Lavrentyev P (1994) Estimates of protozoan bacterivory: from microscopy to ectoenzyme assay? Mar Microb Food Webs 8:71-85

Tanaka T, Taniguchi A (1999) Predator-prey eddy in heterotrophic nanoflagellate-bacteria relationships in a bay on the northeastern Pacific coast of Japan. Mar Ecol Prog Ser 179:123-134

Taylor GT, Iturriaga R, Sullivan CW (1985) Interactions of bacterivorous grazers and heterotrophic bacteria with dissolved organic matter. Mar Ecol Prog Ser 23:129-141

Vrba J, Simek K, Nedoma J, Hartman P (1993) 4-Methylumbelliferyl-N-acetylglucosaminide hydrolysis by a highaffinity enzyme, a putative marker of protozoan bacterivory. Appl Environ Microbiol 59:3091-3101

Zubkov MV, Sleigh MA (1998) Heterotrophic nanoplankton biomass measured by a glucosaminidase assay. FEMS Microbiol Ecol 25:97-106

Zubkov MV, Sleigh MA (2000) Comparision of growth efficiencies of protozoa growing on bacteria deposited on surfaces and in suspension. J Eukaryot Microbiol 47:62-69

Submitted: August 19, 2002; Accepted: August 28, 2003

Proofs received from author(s): December 12, 2003 